\title{
A brief review of socio-economic and environmental impact of Covid-19
}

\author{
Muhammad Farhan Bashir ${ }^{1}$ (D) $\cdot$ Benjiang MA ${ }^{1} \cdot$ Luqman Shahzad $^{1}$
}

Received: 30 June 2020 / Accepted: 27 July 2020 / Published online: 1 August 2020

(C) Springer Nature B.V. 2020

\begin{abstract}
In recent months, Covid-19 has caused significant global social and economic distress. Governments and health officials around the world have introduced mandatory preventive measures to combat Covid-19, i.e., hand sanitizers, gloves, and masks, which have contributed to large quantities of medical wastes. Social distancing and mandatory lockdown have also been put in place to protect people from Covid-19. This epidemic has caused severe demographic changes and unemployment, and economic activities have been shut down to save human lives. Transportation and travel industries are most severely hit as global tourism has fallen to almost zero in recent months; as a solution, economic institutes have introduced stimulus packages worth more than $\$ 6$ trillion. However, restricted economic activities have also contributed towards a cleaner environment. However, environmental changes are not permanent, and the pollution level may rise again in the future. As a result, current research suggests that policymakers must introduce stringent environmental policies to promote clean energy.
\end{abstract}

Keywords Covid-19 $\cdot$ Air quality $\cdot$ Pollution $\cdot$ Economic forecast

\section{Introduction}

In December 2019, Wuhan City (China) experienced unusual pneumonia cases, which were associated with a wet market for the consumption of wild animals (Xu et al. 2020). Such cases were reported to WHO, and in January 2020, this novel coronavirus was named Covid-19. Research and Development department of WHO used diagnostics and therapeutics measures by using reverse polymerase chain reactions and genome sequencing for preliminary laboratory experiments (Wang et al. 2020a, b). Subsequently, in January 2020 , WHO declared a worldwide health emergency due to the rapid rate of infections in mainland China and the rest of the world. Though WHO was criticized for over delayed response and lack of specific health guidelines as North

Muhammad Farhan Bashir

farhan.paks@csu.edu.cn; farhan.paks89@gmail.com

Benjiang MA

mabenjiang@126.com

Luqman Shahzad

luqmanshahzad1975@gmail.com

1 School of Business, Central South University, Changsha 410083, Hunan, People's Republic of China
America and Europe were severely affected by the Covid-19 outbreak. Also, a number of countries, including the USA, the UK, and the European Union, questioned the lack of WHO's response towards the origins of Covid-19. Until February 2020, China suffered the bulk of mortality and new cases, while neighboring Asian regions, North America (Bashir et al. 2020a) and Europe, remained relatively safe (Chakraborty and Maity 2020).

Covid-19 belongs to coronaviruses family, which not only affects humans but can also transmit to animals as well (Kooraki et al. 2020). Bynoe and Tyrell in 1966 were the first ones to study coronaviruses by extracting them from patients suffering from the common cold and called it coronavirus due to the surface's resemblance with a solar corona, which has four further subfamilies, i.e., gamma, beta, delta, and alpha coronaviruses. Beta- and Alphacoronaviruses originate from bats, while delta and gamma coronaviruses mostly affect birds and pigs (Ather et al. 2020). The genome structure of coronavirus ranges from 26 to $32 \mathrm{~kb}$. Betacoronaviruses are associated with severe diseases, while Alphacoronaviruses are attributed to asymptomatic infections. Covid-19 belongs to beta category, and its origin can be linked to the SARS outbreak as its genome structure is $96 \%$ similar to bat coronaviruses (Cao et al. 2020; Kucharski et al. 2020). According to health experts, COVID-19 has originated from the animal trading market in Wuhan, China. Though the lack of research to identify 
intermediate hosts received little or no initial attention, and as a result, the exact route to human infections remains unknown. The main medical symptoms of Covid-19 are similar to pneumonia (Li et al. 2020; Zhou et al. 2020).

\section{Covid-19 and environmental impact}

The announcement of Covid-19 as a global pandemic has also contributed to logistical and environmental issues, i.e., medical waste. Such as, on February 24, 2020, Wuhan, the epicenter of Covid-19, produced over 200 tons of medical waste, which is four times the actual capacity of waste disposal facilities in the city. Therefore, we estimate that the number of confirmed cases is directly correlated with clinical waste. It is why waste management companies around the world are taking necessary steps to ensure that medical centers treating Covid-19 patients are decontaminated as early as possible. However, individuals must take responsibility to ensure compliance with health guidelines (Luan and Ching 2020) as collective determination will ensure that we emerge stronger than ever when this epidemic is over (Fig. 1).

Medical waste is associated with adverse health effects, and people who make direct contact with such waste, i.e., trash collectors, cleaners, and medical staff, can spread virus quickly as they spend most of their time in public places. To ensure public safety protocols, governments introduced quarantine measures to control the infection. However, cleaning staff was the only exception to such regulations, which also makes them vulnerable to getting infected. Furthermore, they are susceptible to other pathogens while disposing of medical waste, i.e., Hepatitis B and meningitis, among others. Face masks are one of the major components of medical wastes, which are discarded after using it for a limited time. Surgical masks are the standard face masks with the expected use of one day, and sanitizer bottles are contributing to environmental pollution, especially in the urban coastal areas. For example, Hong Kong, one of the commercial hubs of the world, faced the Covid-19 pandemic in January 2020, and there is sufficient evidence that since then, its coastal areas have been most affected by medical waste. Ocean Asia, one of the leading NGOs, released the findings of an official survey that medical waste has severely damaged the coastal environment in Hong Kong. They further commented that historically percentage of medical waste is low, but now a new wave of deposits is arriving at the coast with every current (Hellewell et al. 2020).

\section{Covid-19 and socioeconomic changes}

Socioeconomic and demographic factors indicate that Covid19 is not affecting everyone in the same way (Collivignarelli et al. 2020). To fully comprehend that why infectious pandemics affect different socioeconomic groups differently is quite difficult, with data credibility as the key concern. Important socioeconomic indicators such as education, rural or urban area, the density of population, and the number of tenants in a household are important as, unfortunately, Covid19 has a more significant impact on poor areas (Messner 2020. Existing Covid-19 literature indicates that residential areas with lower mean income are likely to be at a greater danger of getting infected than areas with higher income as a research project about New York City has shown that poor residential areas have a much higher infection rate than other areas of the city. The following are some indicators, which likely contribute to the spread of Covid-19:

1. Higher population density means social distancing is challenging to ensure in urban areas.

2. A household with more residents can result in people getting infected without much social contact with other
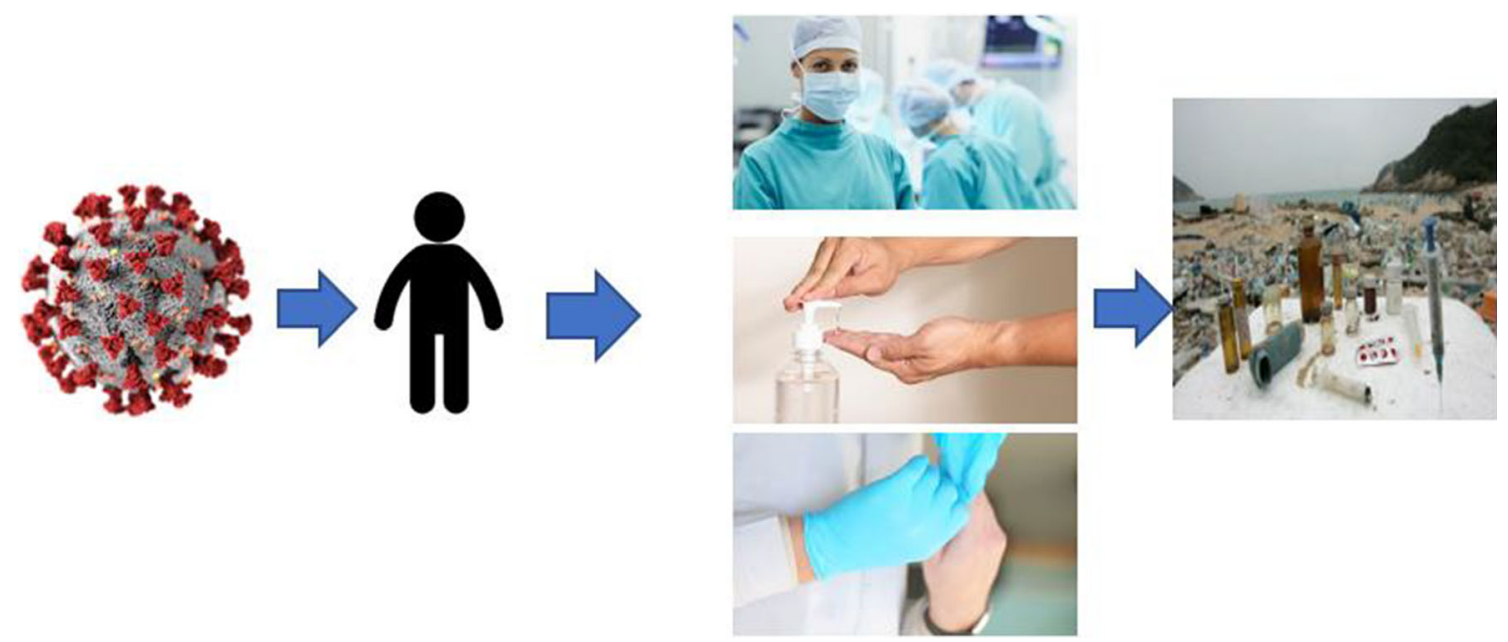

Fig. 1 Illustration of medical waste 
people as one person can bring the virus and infect the others.

3. Social distancing is a preventive approach worldwide which has ensured that Covid-19 can be contained. However, several reasons can contribute to different results:

a. Different regions might adopt different official policies for Covid-19, i.e., official advice varies drastically in the USA, where bordering cities and states have adopted different strategies to combat Covid-19 (Bashir et al. 2020a).

b. Home offices can limit social contacts with other people, but only higher socio-economic jobs can benefit from this, with a limited number of people benefiting from this scenario.

c. Official regulations to avoid going out can be counterproductive for densely populated areas.

d. Patients already suffering from chronic illnesses are at higher risk than healthy people (Giannis et al. 2020; Zheng et al. 2020).

e. WHO has issued health advisories that people who smoke a lot are in much higher risk as smoking and Covid-19 both target lungs.

f. Resident areas with a lower socioeconomic condition are at higher risk because of the lack of healthcare services, i.e., India, Pakistan, Bangladesh, etc. (Singh and Chauhan 2020).

Hence, we can safely conclude that socioeconomic demographics are at the center of the Covid-19 pandemic, which is why higher infections and mortality rates are associated with densely populated areas. Covid-19 also has a significant impact over industrial and economic activities, and implementation of complete and partial lockdown strategies is ensuring that post-Covid economic and social goals will be in stark contrast with the pre-Covid-19 timeline. Table 1 provides a global outlook for a shift in GDP.

(Source: World Economic Outlook Database, I.M.F.)

Covid-19 has created a significant environmental impact in the short term. After an initial struggle to come up with the correct preventive measure, China has limited international arrivals to combat the pandemic (Bogoch et al. 2020). Similarly, North American and European countries are yet to implement a systematic strategy to deal with widespread infection (Fattorini and Regoli 2020). Furthermore, the lack of resources hinders the government efforts to implement a preventive measures like China and South Korea (Zhu et al. 2020). Also, questions are being asked how densely populated countries such as Pakistan, India, Bangladesh, and middleeastern countries are handling Covid-19, where social customs involve large gatherings and public healthcare systems and government response are ill-equipped. Also, institutional
Table 1 Past and projected global economic positions

\begin{tabular}{lccc}
\hline Economic territories & Current & Forecast & \\
\cline { 2 - 4 } & 2019 & 2020 & 2021 \\
\hline World output & 2.9 & -3.0 & 5.8 \\
USA & 2.3 & -5.9 & 4.7 \\
Euro Area & 1.2 & -7.5 & 4.7 \\
Germany & 0.6 & -7.0 & 5.2 \\
France & 1.3 & -7.2 & 4.5 \\
Italy & 0.3 & -9.1 & 4.8 \\
Spain & 2.0 & -8.0 & 4.3 \\
Japan & 0.7 & -5.2 & 3.0 \\
United Kingdom & 1.4 & -6.5 & 4.0 \\
Canada & 1.6 & -6.2 & 4.2 \\
Other advanced economies & 1.7 & -4.6 & 4.5 \\
Emerging and developing economies & 3.7 & -1.0 & 6.6 \\
Emerging and developing Asia & 5.5 & 1.0 & 8.5 \\
China & 6.1 & 1.2 & 9.2 \\
India & 4.2 & 1.9 & 7.4 \\
ASEAN-5 & 4.8 & -0.6 & 7.8 \\
Emerging and developing Europe & 2.1 & -5.2 & 4.2 \\
Russia & 1.3 & -5.5 & 3.5 \\
Latin America and Caribbean & 0.1 & -5.2 & 3.4 \\
Brazil & 1.1 & -5.3 & 2.9 \\
Mexico & -0.1 & -6.6 & 3.0 \\
Middle East and Central Asia & 1.2 & -2.8 & 4.0 \\
Saudi Arabia & 0.3 & -2.3 & 2.9 \\
Sub-Saharan Africa & 3.1 & -1.6 & 4.1 \\
Nigeria & 2.2 & -3.4 & 2.4 \\
South Africa & 0.2 & -5.8 & 4.0 \\
Low-income developing countries & 5.1 & 0.4 & 5.6 \\
\hline & & & \\
\hline
\end{tabular}

reforms must be put in place to minimize the second peak of Covid-19, especially in South Asian, African, and South American countries, to improve public health systems. As a preventive measure, these countries closed down international travel but not before Covid-19 had already infected a significant number of citizens, which shows these countries need to introduce additional preventive measures i.e., (i) restricting entry of people already infected with Covid-19; (ii) implementing health emergencies; and (iii) trying to minimize the psychological, social, and economic impact (Chinazzi et al. 2020). Based on historical analysis, health experts are worried that the second wave of the Covid-19 outbreak could be more fatal than the current one.

Furthermore, domestic and international trade has been severely impacted by the Covid-19 outbreak (Goodell and Huynh 2020). Economic institutes such as I.M.F. and World Bank are concerned with the economic impact of Covid-19, loss in international trade, and slowdown of domestic 
economies (Table 1) is evident (Kharas and Hamel 2020) as economists are still struggling to come up with the economic loss which will be far greater than the cost of preventive measure put in place to combat Covid-19 (Anderson et al. 2020; Meo et al. 2020). Since the pandemic, stock exchange markets faced increased pressure from investors, and in February 2020, stock markets observed the largest decline since 2008 financial crisis with market slide continue in March as global markets fell by several percentages. Furthermore, according to economic forecasts, the economic impact on trade and travel industry, which are the biggest components of the global supply chain, is in trillions and rising. To overcome the economic impact, central banks are easing financial conditions though interest rate cuts to provide $\$ 6$ trillion economic stimuli, which covers credit and liquidity facilities, and F.X. Swap lines. Also, governments are addressing financial vulnerabilities lowering corporate lending in proportion to the GDP ratio. Economic reforms are also targeting factor market limitations as medium and large business enterprises depend heavily on capital and labor markets. Additionally, in an effort to halt economic recession, lending institutes have suspended a principal and interest payments for eligible businesses. Figures 2, 3, and 4 show the impact of Covid-19 on the global economic outlook.

\section{Do we need to bring new regulations to combat Covid-19?}

Covid-19 presents a unique social and economic challenge, and specific health strategies must be put in place to safeguard the elderly, children, and health workers to prevent person-toperson infections (Kucharski et al. 2020). WHO has introduced health guidelines for medical workers and bioscientists who are contributing to finding a cure for novel coronavirus (Mossa-Basha et al. 2020). The vast majority of fatalities from Covid-19 in western and north American regions are in nursing homes for elderly pensioners, due to the weak immune system, which cannot produce antibodies to fight this viral infection (Luan and Ching 2020). Possible transmission routes of Covid-19 can be restricted if access to contaminated items can be limited to a few people. Another possible measure is to provide Covid-19 screening tests at the ports of entry and exit so that countries can timely detect nonlocal cases.

Moreover, research projects must be timely funded to detect epidemiological alterations in the genome of coronavirus. Lastly, the widespread outbreak of Covid-19 in a short period has meant that several questions are still unanswered, i.e., the number of tests conducted and analyzed for Covid-19, percentage of positive results from Covid-19 tests, and close monitoring of Covid-19 infection trends. Also, Covid-19 cases in infants and children are very few, which may be due to less attention to test infants (Rothan and Byrareddy 2020).

\section{Covid-19, quarantine policy, and impact on air quality}

The social and economic landscape has drastically changed in the past few months. Worldwide, millions of cases have been confirmed with Covid-19; as a consequence, governments around the world have introduced lockdown measures to ensure the safety of their citizens. The UK has advocated selfisolation for up to 2 weeks as social distancing has become a new norm. On July 11, 2020, Italy has introduced travel restrictions on 13 countries to combat the Covid-19 pandemic and urged its citizens to avoid international travel (Shehzad et al. 2020). All these measures are helping governments around the world to limit the exposure from Covid-19 (Zambrano-Monserrate and Ruano 2020). As a consequence, transportation, businesses, and industrial shutdowns have contributed towards a significant drop in GHG emissions, i.e., in comparison with 2019, air pollutants in New York have dropped by $50 \%$, coal use in China has decreased by $40 \%$, and a $25 \%$ reduction in GHG emissions has been recorded in the last 3 months (Gautam 2020). Furthermore, the Ministry of Environment, China, recently revealed that AQI has
Fig. 2 Global outlook for merchandise trade (Source: World Economic Outlook Database, I.M.F)

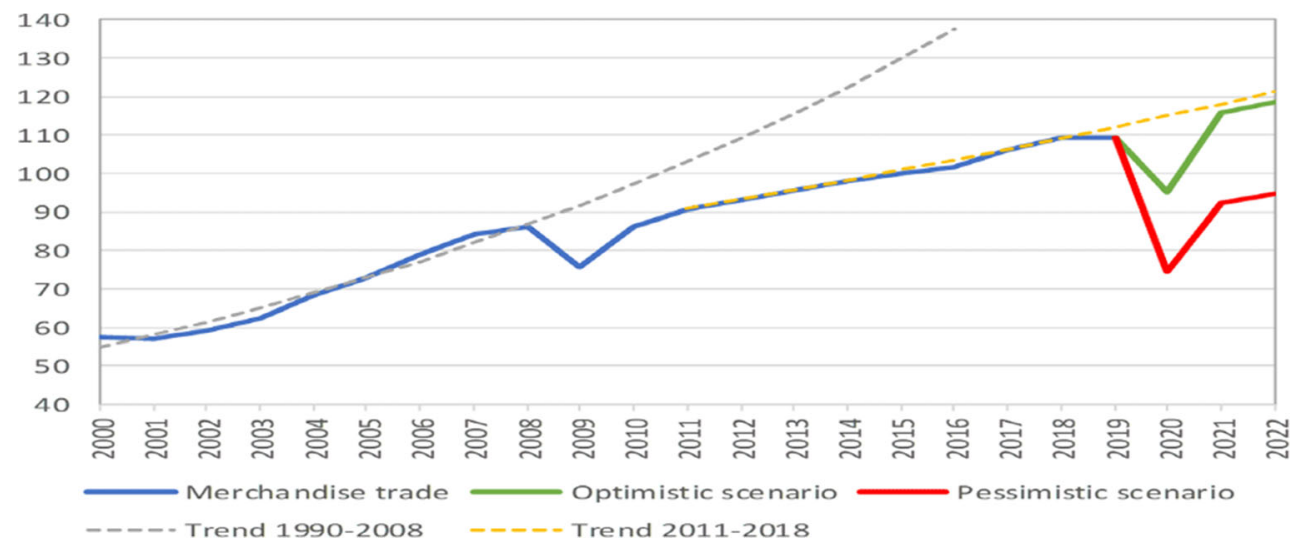


Fig. 3 Global trade and GDP (Source: World Economic Outlook Database, I.M.F)

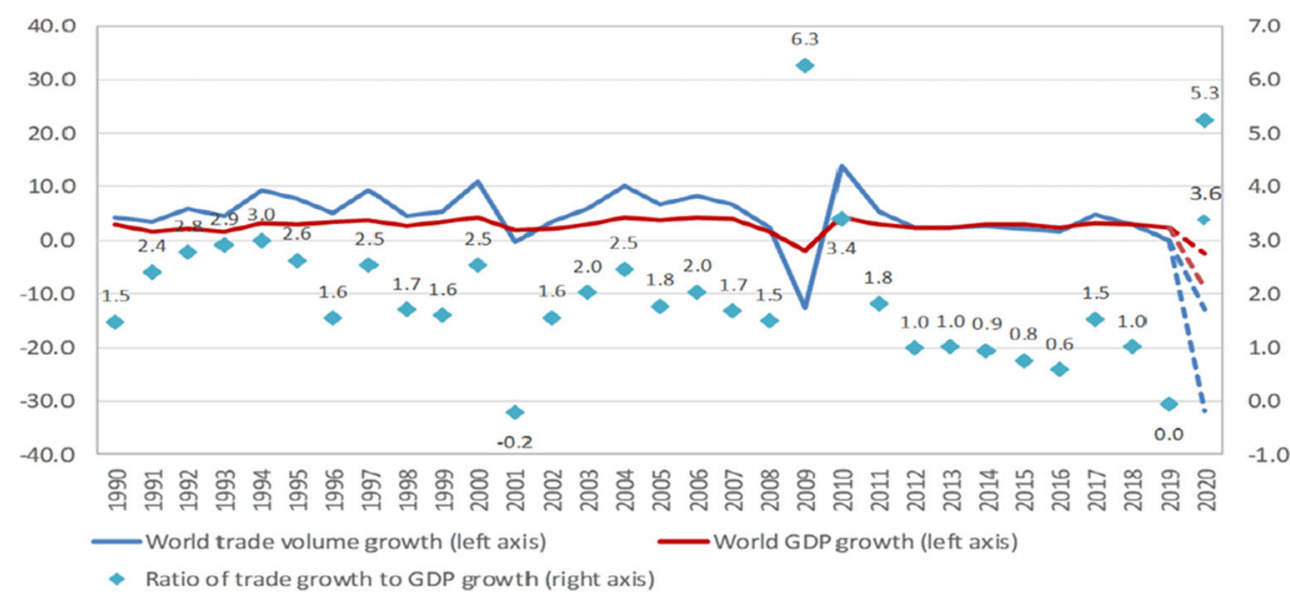

improved by $11.4 \%$ in major cities across China. Berman and Ebisu (2020) articulated that particulate matter and $\mathrm{NO}_{2}$ emissions have been significantly reduced in industrial economies such as OECD, BRICS, G-7, and ASEAN. Though economic impacts of Covid-19 are significant, it has contributed to ecosustainable and decarbonized environment. Nevertheless, environmental advocates argue that resumption of large scale industrial activities will likely reverse the environmental changes (Bernauer and Slowey 2020). Several researchers (Bashir et al. 2020b; Bogoch et al. 2020) suggest that only green legislation will ensure environmental protection for the long term (Fig. 5).

Air quality has improved significantly, especially as Covid19 has been a catalyst in lower emissions of air pollutants in industrial economies as airborne transmissions of carbon monoxide, nitrous oxide, and carbon dioxide have fallen significantly. After analyzing the air quality index in Italy, Conticini et al. (2020) concluded that PM2.5, PM10, and $\mathrm{NO}_{2}$ had been reduced by up to $30 \%$ in recent months. Similarly, Wang et al. (2020a) reported a significant drop in air pollution due to limited industrial activities and transportation facilities and further concluded that limited fossil fuel consumption will contribute in lower emissions into the earth's atmosphere as less demand for coal, gasoline, and diesel is ensuring clean environment around the world (Sharif et al. 2020). Satellite images from NASA to evaluate the impact of air quality during the Covid-19 pandemic indicate that $\mathrm{NO}_{2}, \mathrm{SO}_{2}$ and other environmental pollutants in major epicenters, i.e., Korea, China, Spain, Germany, and the USA have decreased by $20-38 \%$ in comparison with the same time in 2019 (Knowland et al. 2020)

\section{Conclusion}

The Covid-19 is an infectious virus, which has resulted in 13.4 million people getting infected and more than 580,000 deaths across the world. However, Covid-19 also resulted in lower environmental pollution. However, due to devastating human and economic pain, Covid-19 must not be attributed to these positive changes. Covid-19 has significantly affected industrial and emerging economies as it has contributed to the worst stock exchange performance since the 2008 financial crisis. To overcome this, economic institutions have provided more than $\$ 6$ trillion as of the economic stimulus package, including providing coverage for credit and liquidity facilities, and FX swap lines as economies around the world are resuming normal operations, environmentalists suggest that it will lead to higher environmental pollution as industries try to fulfill consumer demands; it is current research initiative suggests
Fig. 4 Global manufacturing and services outlook (Source: World Economic Outlook Database, I.M.F)

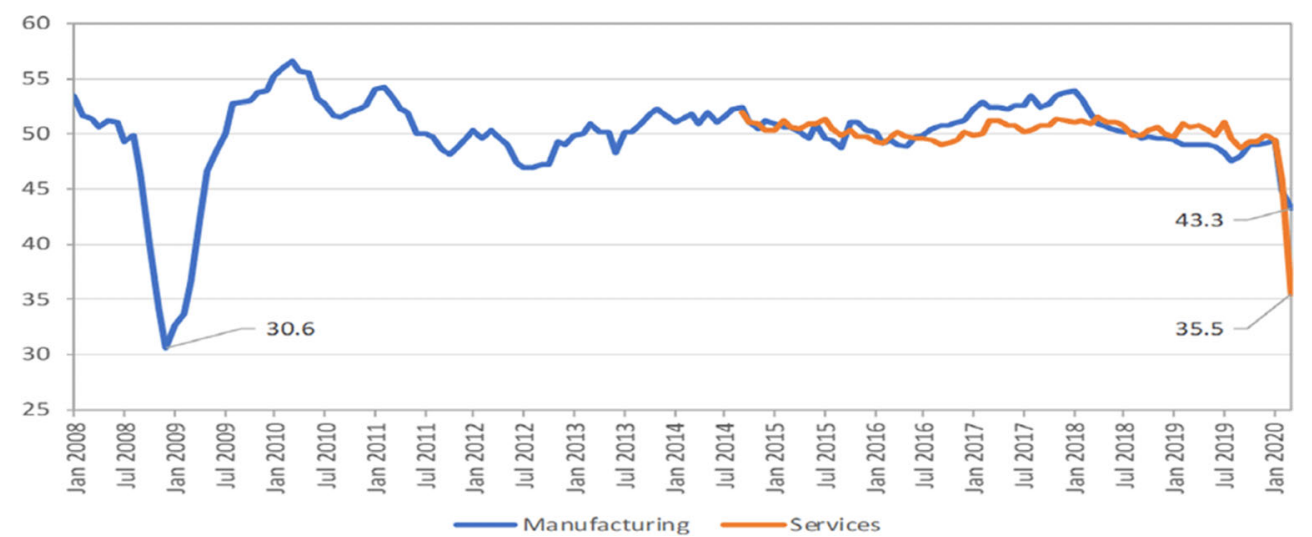


Fig. 5 Before and after air quality comparison of the major cities around the world
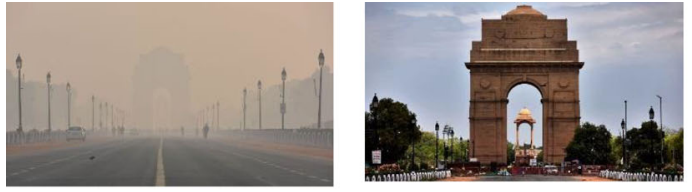

New Delhi, India
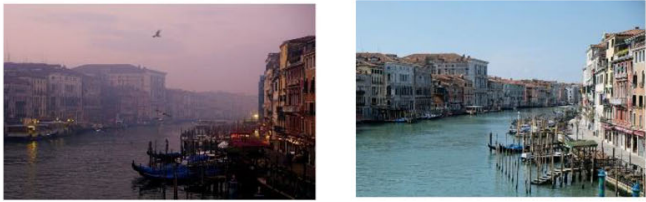

Venice, Italy

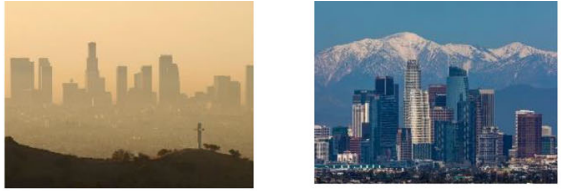

Los Angeles, California
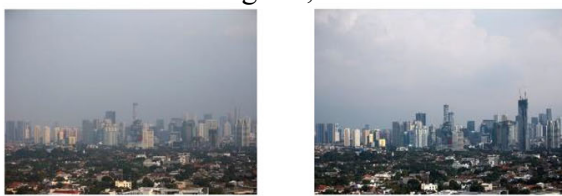

Jakarta, Indonesia that policymakers must bring significant changes in environmental regulations to protect current environmental changes. Additionally, general health reforms must address the Covid19 infectious rate to limit this outbreak, and health workers, elderly, and children must be given special attention to protecting them from the Covid-19 pandemic. Governments around the world must ensure that medical staff and researchers are following WHO guidelines to protect human lives. We also conclude that elderly nursing homes are hotspots for Covid-19-related mortality rates in Europe, Asia, and North America as pensioners have weak immune systems, which is contributing significantly towards the higher death toll of these regions. Another safeguard measure is to provide sanitizing facilities at public places to reduce Covid-19 transmission. Furthermore, the genome structure of Covid-19 must be studied by scientists to give us a better understanding of the spread, adoption, and progress of Covid19 between humans. Lastly, few medical questions remain unanswered, i.e., the number of people tested, the ratio of positive tests, and whether or not this ratio is constant across different regions and countries.

Funding information We acknowledge the financial support by the Ministry of Education-China Mobile Joint Laboratory Grant Number: 2020MHL02005.

\section{References}

Anderson RM, Heesterbeek H, Klinkenberg D, Hollingsworth TD (2020) How will country-based mitigation measures influence the course of the COVID-19 epidemic? Lancet 395(10228):931-934. https://doi. org/10.1016/S0140-6736(20)30567-5

Ather A, Patel B, Ruparel NB, Diogenes A, Hargreaves KM (2020) Coronavirus disease 19 (COVID-19): implications for clinical dental care. J endodon 46:584-595. https://doi.org/10.1016/j.joen.2020. 03.008

Bashir MF, Ma B, Bilal, Komal B, Bashir MA, Tan D, Bashir M (2020a) Correlation between climate indicators and COVID-19 pandemic in New York. USA Sci Total Environ 728:138835. https://doi.org/10. 1016/j.scitotenv.2020.138835

Bashir MF, Ma BJ, Bilal, Komal B, Bashir MA, Farooq TH, Iqbal N, Bashir M (2020b) Correlation between environmental pollution indicators and COVID-19 pandemic: a brief study in Californian context. Environ Res 187:109652. https://doi.org/10.1016/j.envres. 2020.109652

Berman JD, Ebisu K (2020) Changes in U.S. air pollution during the COVID-19 pandemic. Science of The Total Environment 739: 139864. https://doi.org/10.1016/j.scitotenv.2020.139864

Bernauer W, Slowey G (2020) COVID-19, extractive industries, and indigenous communities in Canada: notes towards a political economy research agenda. Extrac Indust Soc. https://doi.org/10.1016/j. exis.2020.05.012

Bogoch II, Watts A, Thomas-Bachli A, Huber C, Kraemer MU, Khan K (2020) Pneumonia of unknown etiology in Wuhan, China: Potential for International Spread Via Commercial Air Travel. J Trav Med 27. https://doi.org/10.1093/jtm/taaa008

Cao YC, Deng QX, Dai SX (2020) Remdesivir for severe acute respiratory syndrome coronavirus 2 causing COVID-19: an evaluation of the evidence. Trav Med Infec Dis:101647. https://doi.org/10.1016/j. tmaid.2020.101647

Chakraborty I, Maity P (2020) COVID-19 outbreak: migration, effects on society, global environment and prevention. Sci Total Environ 728: 138882. https://doi.org/10.1016/j.scitotenv.2020.138882

Chinazzi M, Davis JT, Ajelli M, Gioannini C, Litvinova M, Merler S, Pinotti AP, Mu K, Rossi L, Sun K (2020) The effect of travel restrictions on the spread of the 2019 novel coronavirus (COVID-19) outbreak. Science.:eaba9757. https://doi.org/10.1126/science. aba9757

Collivignarelli MC, Abbà A, Bertanza G, Pedrazzani R, Ricciardi P, Miino MC (2020) Lockdown for CoViD-2019 in Milan: what are the effects on air quality? Sci Total Environ 732:139280. https://doi. org/10.1016/j.scitotenv.2020.139280

Conticini E, Frediani B, Caro D (2020) Can atmospheric pollution be considered a co-factor in extremely high level of SARS-CoV-2 lethality in northern Italy? Environ Pol:114465. https://oi.org/10. 1016/j.envpol.2020.114465

Fattorini D, Regoli F (2020) Role of the atmospheric pollution in the Covid-19 outbreak risk in Italy. MedRxiv. 264:114732. https://doi. org/10.1016/j.envpol.2020.114732

Gautam S (2020) COVID-19: air pollution remains low as people stay at home. Air Qual Atmos Heal 13:853-857. https://doi.org/10.1007/ s11869-020-00842-6

Giannis D, Ziogas IA, Gianni P (2020) Coagulation disorders in coronavirus infected patients: COVID-19, SARS-CoV-1, MERS-CoV and lessons from the past. J Clin Vir:104362. https://doi.org/10.1016/j. jcv.2020.104362

Goodell JW, Huynh TLD (2020) Did congress trade ahead? Considering the reaction of U.S. industries to COVID-19. Finance Research Letters, 101578. https://doi.org/10.1016/j.frl.2020.101578

Hellewell J, Abbott S, Gimma A, Bosse NI, Jarvis CI, Russell TW, Munday JD, Kucharski AJ, Edmunds WJ, Sun F (2020) 
Feasibility of controlling COVID-19 outbreaks by isolation of cases and contacts. Lancet Glob Heal 8:e488-e496. https://doi.org/10. 1016/S2214-109X(20)30074-7

Kharas H, Hamel K (2020) I.M.F.'s World Economic Outlook, Initial Assessment of a country-by-country of what might happen to the world economy in 2020 and 2021: I.M.F

Knowland EK, Keller C, Ott L, Pawson S, Saunders E, Wales P, and Duncan B (2020) Local to Global Air Quality Simulations using the NASA GEOS Composition Forecast Model, GEOS-CF

Kooraki S, Hosseiny M, Myers L, Gholamrezanezhad A (2020) Coronavirus (COVID-19) outbreak: what the department of radiology should know. J Amer coll rad 17:447-451. https://doi.org/10. 1016/j.jacr.2020.02.008

Kucharski AJ, Russell TW, Diamond C, Liu Y, Edmunds J, Funk S, Eggo RM, Suna F, Jit M, Munday JD (2020) Early dynamics of transmission and control of COVID-19: a mathematical modelling study. Lancet infec dis 20:553-558. https://doi.org/10.1016/S14733099(20)30144-4

Li M, Lei P, Zeng B, Li Z, Yu P, Fan B, Wang B, Li Z, Zhou J, Hu S (2020) Coronavirus disease (COVID-19): spectrum of C.T. findings and temporal progression of the disease. Acad Rad. https://doi.org/ 10.1016/j.acra.2020.03.003

Luan PT, Ching CTS (2020) A reusable mask for coronavirus disease 2019 (COVID-19). Arch Med Res 51:455-457. https://doi.org/10. 1016/j.arcmed.2020.04.001

Meo SA, Al-Khlaiwi T, Usmani AM, Meo AS, Klonoff DC, Hoang TD (2020) Biological and epidemiological trends in the prevalence and mortality due to outbreaks of novel coronavirus COVID-19. J K S Uni 32:2495-2499. https://doi.org/10.1016/j.jksus.2020.04.004

Messner W (2020) The institutional and cultural context of cross-national variation in COVID-19 outbreaks. medRxiv. https://doi.org/10. $1101 / 2020.03 .30 .20047589$

Mossa-Basha M, Medverd J, Linnau K, Lynch JB, Wener MH, Kicska G, Staiger T, Sahani D (2020) Policies and guidelines for COVID-19 preparedness: experiences from the University of Washington. Radi 201326. https://doi.org/10.1148/radiol.2020201326

Rothan HA, Byrareddy SN (2020) The epidemiology and pathogenesis of coronavirus disease (COVID-19) outbreak. J autoim 102433: 102433. https://doi.org/10.1016/j.jaut.2020.102433

Sharif A, Aloui C, Yarovaya L (2020) COVID-19 pandemic, oil prices, stock market, geopolitical risk and policy uncertainty nexus in the U.S. economy: Fresh evidence from the wavelet-based approach.
International Review of Fin Analy 70:101496. https://doi.org/10. 1016/j.irfa.2020.101496

Shehzad K, Sarfraz M, Shah SGM (2020) The impact of COVID-19 as a necessary evil on air pollution in India during the lockdown. Environ pol 266:115080. https://doi.org/10.1016/j.envpol.2020. 115080

Singh RP, Chauhan A (2020) Impact of lockdown on air quality in India during COVID-19 pandemic. Air Qual Atmos Heal 13:921-928. https://doi.org/10.1007/s11869-020-00863-1

Wang P, Chen K, Zhu S, Wang P, Zhang H (2020a) Severe air pollution events not avoided by reduced anthropogenic activities during COVID-19 outbreak. Resour Conser Recyc 158:104814. https:// doi.org/10.1016/j.resconrec.2020.104814

Wang D, Hu B, Hu C, Zhu F, Liu X, Zhang J, Wang B, Xiang H, Cheng Z, Xiong Y (2020b) Clinical characteristics of 138 hospitalized patients with 2019 novel coronavirus-infected pneumonia in Wuhan, China. JAMA 323(11):1061-1069. https://doi.org/10.1001/jama. 2020.1585

Xu Z, Shi L, Wang Y, Zhang J, Huang L, Zhang C, Liu S, Zhao P, Liu H, Zhu L (2020) Pathological findings of COVID-19 associated with acute respiratory distress syndrome. Lancet resp med 8(4):420-422. https://doi.org/10.1016/S2213-2600(20)30076-X

Zambrano-Monserrate MA, Ruano MA (2020) Has air quality improved in Ecuador during the COVID-19 pandemic? A parametric analysis. Air Qual Atmos Heal 13:929-938. https://doi.org/10.1007/s11869020-00866-y

Zheng YY, Ma YT, Zhang JY, Xie X (2020) COVID-19 and the cardiovascular system. Nat Rev Card 17(5):259-260. https://doi.org/10. 1038/s41569-020-0360-5

Zhou P, Yang XL, Wang XG, Hu B, Zhang L, Zhang W, Si HR, Zhu Y, Li B, Huang CL (2020) A pneumonia outbreak associated with a new coronavirus of probable bat origin. Nature 579(7798):270-273. https://doi.org/10.1038/s41586-020-2012-7

Zhu Y, Xie J, Huang F, Cao L (2020) The mediating effect of air quality on the association between human mobility and COVID-19 infection in China. Environ Res 189:109911. https://doi.org/10.1016/j. envres.2020.109911

Publisher's note Springer Nature remains neutral with regard to jurisdictional claims in published maps and institutional affiliations. 